TITLE:

\title{
Prostaglandins and chronic inflammation
}

$\operatorname{AUTHOR}(\mathrm{S})$ :

Aoki, Tomohiro; Narumiya, Shuh

CITATION:

Aoki, Tomohiro ... [et al]. Prostaglandins and chronic inflammation.

Trends in pharmacological sciences 2012, 33(6): 304-311

ISSUE DATE:

2012-06

URL:

http://hdl.handle.net/2433/157344

RIGHT:

(C) 2012 Elsevier Ltd.; This is not the published version. Please cite only the published version.; この論文は出版社版でありません。引用の際に は出版社版をご確認ご利用ください。 
6 Department of Pharmacology, Kyoto University Graduate School of Medicine,

7 and Core Research for Evolutional Science and Technology (CREST)

8 Kyoto 606-8501, Japan

9 TEL : $+81-75-753-4392 /$ FAX : $+81-75-753-4693$

11 Tomohiro Aoki; tomoaoki@ kuhp.kyoto-u.ac.jp

12 Shuh Narumiya; snaru@mfour.med.kyoto-u.ac.jp

14 Corresponding author: Shuh Narumiya (snaru@mfour.med.kyoto-u.ac.jp) 


\section{Abstract}

2 Chronic inflammation is the basis of various chronic illnesses including cancer and

3 vascular diseases. However, much has yet to be learned how inflammation becomes

4 chronic. Although prostaglandins (PGs) are well established as mediators of acute

5 inflammation, recent studies in experimental animals have provided evidence that they

6 also function in transition to and maintenance of chronic inflammation. One role PGs

7 play in such processes is amplification of cytokine signaling. As such, PGs can facilitate

8 acquired immunity and induce long-lasting immune inflammation. PGs also contribute

9 to chronic inflammation by making a positive feedback loop and/or by inducing

10 chemokines and recruiting inflammatory cells to alternate active cell populations at

11 affected sites. PGs also contribute to tissue remodeling as seen in angiogenesis and

12 fibrosis. Although such roles of PGs should be verified in human diseases, these

13 findings suggest that PG signaling is a promising therapeutic target of chronic

14 inflammatory diseases. 
1 Involvement of PGs in transition from acute inflammation to chronic

2 inflammation?

3 Inflammation is triggered by various kinds of tissue insults, induces local reddening,

4 heat, swelling, pain and fever, and mostly subsides in a few days. However,

5 inflammation often persists and becomes chronic. Growing evidence now suggests

6 involvement of chronic inflammatory processes in pathogenesis of a variety of diseases

7 including cancer [1], metabolic syndrome [2] and vascular diseases [3]. In these

8 disorders, abundant infiltration of inflammatory cells and expression of various

9 pro-inflammatory molecules are found in affected tissues. Given that chronic diseases

10 have a great impact on social health due to a large number of affected patients and a

11 significant therapeutic cost, understanding mechanisms of transition to and maintenance

12 of chronic inflammation is important. Potential mechanisms contributing to chronic

13 inflammation include i) conversion of acute inflammation to long-lasting immune

14 inflammation, ii) activation of a positive feedback loop by repetitive stimuli, iii)

15 sustenance of inflammation by changing active cell populations in affected tissues, and

16 finally iv) tissue remodeling.

17 Prostaglandins (PGs) including $\mathrm{PGD}_{2}, \mathrm{PGE}_{2}, \mathrm{PGF}_{2 \alpha}, \mathrm{PGI}_{2}$ and thromboxane (TX)

$18 \mathrm{~A}_{2}$ are a group of lipid mediators produced and released in response to various stimuli. 
1 They are synthesized from arachidonic acid by sequential actions of cyclooxygenase

2 (COX) and respective synthases, and exert their actions through a family of $\mathrm{G}$

3 protein-coupled receptors (GPCRs), prostaglandin D receptor (DP), EP1, EP2, EP3 and

4 EP4 subtypes of prostaglandin E receptor, prostaglandin F receptor (FP), prostaglandin I

5 receptor (IP) and thromboxane A receptor (TP), and one GPCR in a different family,

6 CRTH2/DP2 [4]. Because COX is the target of aspirin-like non-steroidal

7 anti-inflammatory drugs (NSAIDs) that effectively suppress various symptoms of acute

8 inflammation, many symptoms of acute inflammation were presumed to be mediated by

9 PGs. Indeed, recent studies using knockout mice deficient in each PG receptor and PG

10 receptor type/subtype-specific agonists and antagonists have identified receptors and

11 mechanisms responsible for PG-mediated inflammatory swelling, fever generation and

12 hyperalgesia [4-6]. More intriguingly, these studies also suggest that PG signaling is

13 involved in transition to and maintenance of chronic inflammation. Here we review

14 experimental evidences to support such a hypothesis and discuss their therapeutic

15 implications.

\section{$17 \quad$ PGs as a cytokine amplifier}

18 Because COX-2 can be induced by lipopolysaccharide (LPS) and pro-inflammatory 
1 cytokines such as interleukin (IL)- $1 \beta$ and IL-6, and COX-1 is constitutively expressed

2 irrespectively of these stimuli, PGs are believed to be formed either independently or

3 downstream of cytokines and innate immunity and elicit inflammatory symptoms.

4 However, recent studies have revealed that PGs often work with cytokines and

5 pathogen- or damage-associated molecular patterns (PAMPs and DAMPs) in various

6 inflammatory settings and amplify cytokine- and PAMP/DAMP-signaling by enhancing

7 expression of inflammation-related genes induced by these stimuli. For example, Honda

8 et al. [7] reported interaction of $\mathrm{PGI}_{2}-\mathrm{IP}$ signaling and $\mathrm{IL}-1 \beta$ in collagen-induced

9 arthritis (CIA) in mice, a model of human rheumatoid arthritis. In this model, IP

10 deficiency did not affect the incidence of arthritis but significantly reduced the extent of

11 arthritis determined by inflammatory cell infiltration, synovial cell proliferation and bone destruction. Cytokine analysis revealed a marked reduction in the content of IL-6 in arthritic paws of IP-deficient mice without affecting production of anti-collagen antibody. Treatment of cultured synovial fibroblasts with indomethacin in vitro significantly reduced the amount of IL- 6 induced by IL-1 $\beta$, and this reduction was rescued by the addition of an exogenous IP agonist. Furthermore, microarray analysis revealed that approximately one-third of 400 genes induced by IL-1 $\beta$ in cultured synoviocytes were suppressed by the PG synthesis inhibitor indomethacin, and 
1 expression of one hundred genes among them was restored by treatment with an IP

2 agonist. The genes whose expression is amplified by IP signaling include; those

3 involved in inflammation such as IL-6, IL-11, and CXCL7; those involved in cell

4 proliferation such as various isoforms of fibroblast growth factor (FGF), vascular

5 endothelial growth factor (VEGF) and hypoxia inducible factor 1 alpha (HIF1 $\alpha$ ); and

6 those involved in tissue remodeling such as receptor activator of nuclear factor kappa-B

7 ligand (RANKL) and members of the a disintegrin and metalloproteinase with

8 thrombospondin motifs (ADAMTS) family. It should be mentioned that $\mathrm{PGI}_{2}$ alone did

9 not induce expression of these genes. Intriguingly, an approximately three-fold increase

10 in expression of IL-1 receptor (IL1R1) was observed with the IP agonist treatment,

11 suggesting that this may be the basis of IP-mediated amplification of IL- $1 \beta$ signaling.

Importance of $\mathrm{PGI}_{2}$ in development of arthritis was confirmed in another mouse model, autoantibody-driven $\mathrm{K} / \mathrm{BxN}$ serum transfer arthritis [8]. Interestingly, $\mathrm{PGI}_{2}$ in this model almost solely derived from COX-1-catalyzed reaction. An example of PG-mediated amplification of PAMP/DAMP-signaling was reported by Oshima et al. [9], who examined interaction of $\mathrm{PGE}_{2}-\mathrm{EP} 4$ signaling and LPS. They stimulated the RAW264.7 macrophage cell line with LPS, and examined the effects of a COX-2 inhibitor, celecoxib, and an EP4 antagonist, RQ-00015986/CJ-42794, on LPS-induced gene 
1

2

3

expression. They found that celecoxib or RQ-00015986 significantly suppressed gene expression of COX-2, IL-1 $\beta$ and IL-6. These results support a role of PGE 2 -EP4 signaling as an 'amplifier' of LPS signaling. Interestingly, the above treatment did not affect induction of microsomal prostaglandin E synthase-1 (mPGES-1) and tumor necrosis factor alpha (TNF- $\alpha)$ by LPS, suggesting selective modulation of gene expression. As described below in more detail, the role of PGs as a 'cytokine amplifier' was also demonstrated in induction of specific $\mathrm{T}$ helper subsets involved in immune inflammation [10]. These findings suggest that, in addition to their actions in acute inflammation, PGs are able to convert short-lived inflammatory responses to long-term gene-expression-dependent processes by facilitating actions of cytokines and/or innate immunity. Recognition of PGs as a 'cytokine amplifier' is conceptually important to understand their roles in chronic inflammation (Figure 1).

\section{PGs in acquired immunity and immune inflammation}

Acquired immunity is initiated by processing and presentation to naïve $\mathrm{T}$ cells of antigen by dendritic cells (DCs), which are then differentiated to specific T cell subsets. The type of immune response is dependent on which $\mathrm{T}$ cell subset is induced to particular antigen. Two distinct subsets of helper T cells, Th1 and Th17, which are 
1 characterized by production of interferon- $\gamma($ IFN- $\gamma$ ) and IL-17, respectively [11], are

2 important cell populations that contribute to pathogenesis of various chronic

3 autoimmune inflammatory diseases. Indeed, in human chronic inflammatory diseases

4 such as multiple sclerosis and Crohn's disease, elevation of IFN- $\gamma$ and IL-17 and

5 accumulation of these $\mathrm{T}$ cell subsets in affected organs (the brain of patients with

6 multiple sclerosis and the gut of patients with Crohn's disease) are reported [12-15].

$7 \quad$ Th1 differentiation is induced by IL-12 and facilitated by IFN- $\gamma$. Th17 differentiation

8 and expansion are induced by TGF- $\beta$ /IL-6 and IL-23, respectively. Disruption of genes

9 for these cytokines or their pharmacological inhibition suppressed disease development

10 or progression in mouse models of the above diseases such as experimental autoimmune

11 encephalomyelitis (EAE) and experimental colitis [16-18].

12 PGs have been traditionally regarded as immuno-suppressants. Indeed, $\mathrm{PGE}_{2} / \mathrm{cAMP}-$ mediated suppression of differentiation of Th1 cells has been repeatedly demonstrated in vitro $[19,20]$. However, recent studies have revealed that, in contrast to traditional belief, PGs are involved in differentiation and expansion of Th1 and Th17 cells (Figure 1). Yao et al. [10] revisited the action of $\mathrm{PGE}_{2}$ on Th1 differentiation. One plausible mechanism of inhibitory action of $\mathrm{PGE}_{2}$ and cAMP on $\mathrm{T}$ cell activation is 
1 kinase, and this is antagonized by T cell receptor (TCR) stimulation. Yao and colleagues

2 added increasing amounts of anti-CD28 to enhance TCR signaling and then examined

3 effects of $\mathrm{PGE}_{2}$ on $\mathrm{T}$ cell differentiation under the Th1 skewing conditions. Intriguingly,

4 under these conditions, $\mathrm{PGE}_{2}$ enhanced IL-12-mediated Th1 differentiation in a

5 concentration-dependent manner from $1 \mathrm{nM}$. This action was mimicked by an EP2 or

6 EP4 selective agonist and abolished in T cells deficient in EP2 and EP4, suggesting that

7 with strengthened TCR stimulation, $\mathrm{PGE}_{2}$-EP2/EP4 signaling enhances rather than

8 suppresses differentiation of T cells to the Th1 subset. They further extended their study

9 and found that $\mathrm{PGE}_{2}-\mathrm{EP} 2 / 4$ signaling facilitates Th17 expansion induced by IL-23 via

10 cAMP [10]. Chen et al. [21] used a selective EP4 antagonist, ER-819762, and also

11 found these actions of $\mathrm{PGE}_{2}$-EP4 signaling on Th1 differentiation and Th17 expansion.

12 Facilitation of IL-23-induced Th17 expansion by $\mathrm{PGE}_{2}-\mathrm{EP} 2 / 4$ signaling was also found

13 in human memory $\mathrm{T}$ cells, in which the $\mathrm{PGE}_{2}$-cAMP pathway up-regulates expression

14 of receptors for IL-23 and IL-1 and synergizes with these cytokines to drive ROR $\gamma \tau$,

15 IL-17, IL-17F, CCL20 and CCR6 expression [22-24]. Thus, PGE 2 functions as a

16 cytokine amplifier also in this case (Figure 1). Another site of expansion of Th17 cells

by $\mathrm{PGE}_{2}$ is $\mathrm{IL}^{2} 23$ production by DCs. Yao et al. [10] demonstrated that IL-23 production from DCs stimulated with anti-CD40 antibody is enhanced by either $\mathrm{PGE}_{2}$ 
1 or an EP4 agonist, and surprisingly, the addition of an EP4 antagonist or indomethacin

2 to this system almost totally suppressed IL-23 production, suggesting that endogenous

$3 \mathrm{PGE}_{2}$ acts on EP4 and enhances IL-23 production from anti-CD40-stimulated DCs.

4 Inhibitory action of EP4 antagonism on IL-23 production by DCs was also found by

5 Chen et al. [21]. Furthermore, it was also shown that $\mathrm{PGE}_{2}$ in combination with

6 Toll-like receptor ligands enhances the production of IL-23 p19 by DCs [25, 26]. In

7 addition to these EP2/EP4-mediated immuno-stimulatory actions of $\mathrm{PGE}_{2}$, Nakajima et

8 al. [27] found that $\mathrm{PGI}_{2}$-IP signaling also facilitates Th1 differentiation. Interestingly,

9 they also reported that this signaling suppresses Th2 differentiation from naïve $\mathrm{T}$ cells

10 from $\mathrm{BALB} / \mathrm{c}$ mice under the Th2 skewing conditions (CD3/CD28 plus IL-4

11 stimulation) [27]. Perhaps consistent with these findings, Takahashi et al. [28] found that loss of IP resulted in elevated IgE level and augmentation of allergic inflammation in mice with OVA-induced allergic asthma.

14 Consistent with its immune-stimulatory effects in vitro, PGE $_{2}$-EP2/EP4 signaling appears to participate in antigen-specific Th1 and Th17 cell differentiation/expansion in

16 vivo and is involved in disease progression of several immune inflammation models.

17 Yao et al. [10] examined the role of $\mathrm{PGE}_{2}$-EP4 signaling in mouse contact 18 hypersensitivity (CHS) and EAE. In these models, Th1 and Th17 cells are thought to be 
1 involved in both induction and exacerbation of diseases. Results showed that treatment

2 with an EP4 antagonist ameliorated both CHS and EAE [10]. Moreover, when

3 researchers examined lymph node cells from the immunized mice, proliferation and

4 production of IFN- $\gamma$ and IL-17 in response to cognate antigen stimulation were

$5 \quad$ significantly reduced in mice treated with the EP4 antagonist [10]. EP2 and EP4 appear

6 to function redundantly in elicitation of EAE, because the EP4 antagonist suppresses T

7 cell activation and disease progression more potently when administered to

8 EP2-deficient mice than to wild-type mice [10]. Consistent with the

9 immuno-stimulatory action of EP4, Chen et al. [21] examined effects of ER-819762 on

10 CIA, and found that administration of this antagonist ameliorated progression of

11 arthritis with concomitant suppression of Th1 and Th17 production by lymph node cells.

12 These results suggest that $\mathrm{PGE}_{2}$-EP4 signaling functions in immunization processes,

13 and blocking this signaling leads to suppression of Th1 differentiation and Th17

14 expansion. Sheibanie et al. [29] used 2,4,6-trinitrobenzene sulfonic acid

15 (TNBS)-induced colitis, an animal model of Crohn's disease, and found that

16 intraperitoneal (i.p.) administration of $\mathrm{PGE}_{2}$ or misoprostol, an EP3/EP4 agonist,

17 exacerbated colitis and concomitantly increased expression of IL-23 p19, IL-17, IL-1 $\beta$,

18 TNF- $\alpha$ and IL-6 in the colon. They also reported that misoprostol administration 
1 exacerbated CIA in mice, and increased expression of IL-23 p19 and IL-17 at the joint

2 [30]. Taken together, these results suggest that $\mathrm{PGE}_{2}$-EP2/EP4 signaling facilitates Th1

3 differentiation and Th17 expansion in vivo in various models of immune diseases.

4 Consistent with this, recent genome-wide analysis identified PTGER4 (EP4) as a locus

5 associated with Crohn's disease [31] and multiple sclerosis [32]. In the former, risk

$6 \quad$ SNPs in this locus are associated with increased EP4 expression [31].

7

8

9 hemodynamic stress occurs, hemodynamic stress is believed to trigger IA formation.

\section{$\mathrm{PGE}_{2}$ in a positive feedback loop for inflammation}

One possible mechanism for sustaining inflammation is a positive feedback loop to amplify the initial signal. Indeed, the presence of such a positive feedback loop involving PGs and its contribution to pathogenesis have been shown in animal models of chronic inflammatory diseases such as intracranial aneurysm (IA) and cancer. IA is a regional bulging of intracranial arteries (mostly at their bifurcation) and is histologically characterized by arterial wall degeneration, inflammatory cell infiltration and NF- $\kappa \mathrm{B}$ activation. IA is found in 1 to $5 \%$ of the general population [33] and is a major cause of subarachnoid hemorrhage [34]. Because most IAs occur at bifurcation where high

However, how hemodynamic stress leads to chronic inflammation remained unclear. 
1 Aoki et al. [35] used an animal model of IA, and demonstrated that the chronic

2 inflammatory response is induced by a positive feedback loop consisting of

3 COX-2-PGE 2 -EP2-NF-кB. They found induction of COX-2 expression in endothelial

4 cells at the prospective site of aneurysm formation in vivo, which was mimicked in vitro

5 in cultured endothelial cells subjected to shear stress. Celecoxib treatment suppressed

6 IA formation, suggesting the importance of COX-2 in the pathogenesis of IA. They

7 further found that EP2 is upregulated at the site of IA, and mice deficient in EP2 are

8 selectively protected from IA. Furthermore, COX-2 inhibition suppressed EP2

9 expression and EP2 deficiency suppressed COX-2 induction in IA walls. These two

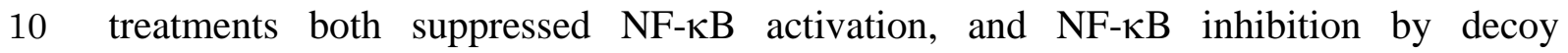

11 oligonucleotides suppressed COX-2 expression in the IA model. Because activated

$12 \mathrm{NF}-\kappa \mathrm{B}$ induces various inflammation-associated genes, including MCP-1 (CCL2),

13 COX-2 inhibition and EP2 deficiency both reduced MCP-1 expression and suppressed

14 macrophage infiltration. Thus, hemodynamic stress triggers COX-2 induction, and

$15 \mathrm{COX}-2, \mathrm{PGE}_{2}, \mathrm{EP} 2$ and NF- $\mathrm{B}$ make a positive feedback loop to amplify inflammatory

16 signals (Figure 2).

17 Inflammation promotes tumourigenesis and is very often associated with cancer.

18 One of the hallmarks of tumor-associated inflammation is expression of COX-2, though 
1 COX-1 can also contribute to tumourigenesis [36]. Pharmacological inhibition and

2 genetic deletion of $\mathrm{COX}$ isoforms prevent precancerous adenomas in humans and

3 experimental animals and reduces colorectal cancer incidence in humans [37-39]. To

4 identify the responsible PG receptor for COX-mediated tumourigenesis, Sonoshita et al.

5 [40] made compound mutant mice of mice deficient in EP1, EP2 or EP3 and APC ${ }^{\Delta 716}$

6 mice, a model of human familial adenomatous polyposis. They found that loss of EP2

7 selectively decreases the number and size of intestinal polyps in $\mathrm{APC}^{\Delta 716}$ mice. They

8 also demonstrated that EP2 is strongly induced and expressed in the same stromal

9 region of polyps as COX-2, and that loss of EP2 almost completely suppresses COX-2

10 induction in polyp tissues, suggesting a positive feedback loop between $\mathrm{PGE}_{2}, \mathrm{EP} 2$ and

$11 \mathrm{COX}-2$, as in IA. Furthermore, deletion of either COX-2 or EP2 suppresses induction of

12 VEGF, angiopoetin-2 and laminin- $\alpha 2$ in polyps. These results suggest that the

13 COX-2-PGE 2 -EP2 loop functions in amplification of tumourigenesis-associated genes.

14 Although the Sonoshita's study did not identify involvement of NF- $\kappa B$ in the positive

15 feedback loop, its involvement was indicated recently in a separate study by Shin et al.

16 [41]. They examined effects of nicotine on proliferation of the human gastric

17 adenocarcinoma (AGS) cell line. Nicotine, a component of cigarette smoke, has been

18 reported to promote tumor growth [42]. Shin et al. [41] analyzed microRNAs induced 
1 by nicotine treatment of AGS cells and found upregulation of miR-16 and miR-21,

2 which are known to be associated with gastric cancer. They further found that induction

3 of these miRNAs is mediated by NF- $\kappa \mathrm{B}$, and dependent on COX-2, EP2 and EP4. On

4 the basis of these findings, the authors suggested that nicotine upregulates miR-16 and

5 miR-21 in gastric cancer cells via EP2 and EP4 receptor-mediated NF- $\kappa \mathrm{B}$

6 transcriptional activation. Given that NF- $\mathrm{BB}$ activity regulates COX-2 expression in

7 many cases of tumourigenesis [43-45], these combined results suggest the presence of

8 the COX-2-PGE 2 -EP2/4-NF- $\mathrm{KB}$ loop that can amplify inflammation associated with

9 tumourigenesis. However, the above three studies [43-45] were carried out in rather

10 simplified model systems, one being polyposis and the other cultured cells, and did not

11 address the role of inflammation directly. Therefore, detailed cross-talk between

12 inflammation and tumors and the significance of PG signaling, EP2 in particular, should

13 be examined in more suitable inflammation-associated colon cancer models such as

14 azoxymethane-dextran sodium sulfate model [46].

PGs and recruitment of inflammatory cells

At inflammatory sites, abundant infiltration of inflammatory cells such as neutrophils, eosinophils and macrophages is seen, and recruitment of these cells is 
1 mostly carried out by expression of chemokines. There is now substantial evidence that

2 PGs are involved in induction of chemokines and resultant infiltration of inflammatory

3 cells at the inflamed site (Figures 2 and 3). For example, as discussed above, the

$4 \mathrm{PGI}_{2}$-IP signaling synergizes with IL-1 $\beta$ in CIA to augment expression of CXCL7, a

5 chemokine for neutrophils, fibroblasts and endothelial cells [7]. In IA, one of the

6 genes induced by the $\mathrm{PGE}_{2}-\mathrm{EP} 2-\mathrm{NF}-\kappa \mathrm{B}$ pathway in endothelial cells is MCP-1, which

7 recruits and activates macrophages to infiltrate the vessel wall [35]. Recruited

8 macrophages then produce a variety of pathological molecules such as cytokines and

9 proteinases [47, 48]. The contribution of MCP-1-mediated macrophage recruitment to

10 the pathogenesis of IA was well defined by in vivo experiments using MCP-1-deficient

11 mice, using a dominant negative form of $\mathrm{MCP}-1$ or chlodronate liposome to deplete

12 macrophages [47, 49]. Depletion of macrophages or the inhibition of MCP-1

13 remarkably prevented IA formation through the suppression of macrophage-evoked

14 inflammation. Thus, the PG signaling induces switching of active cell populations

15 participating in inflammation of affected tissues. In a model of Helicobacter pylori-infected gastric tumor, Oshima et al. [9] found that bacterial colonization and $\mathrm{PGE}_{2}$ signaling through EP4 cooperatively induced the expression of MCP-1, and this 
1 tumor-associated macrophages to promote gastric tumors. In the Lewis lung tumor

2 transplantation model, Katoh et al. [50] found COX-2 dependent CXCL12 (SDF1 $\alpha$ )

3 expression in stromal fibroblasts surrounding the tumor, which is significantly

4 attenuated in mice deficient either EP3 or EP4, and is reproduced by the addition of

5 EP3- or EP4-selective agonists. CXCL12 is a chemokine for CD34 ${ }^{+}$bone marrow cells,

6 T cells, B cells and DCs, and in the above study, the authors suggested that the cells

7 recruited from bone marrow function for angiogenesis [50]. By contrast, Wang et al.

8 [51] detected high levels of expression of CXCL1 in human colorectal cancers and

9 adenomas of $\mathrm{Apc}^{\mathrm{min}}$ mice. They further found that CXCL1 is induced by $\mathrm{PGE}_{2}$ in vitro

10 in cultured colon cancer cell lines, and showed that some of the $\mathrm{PGE}_{2}$ effects on tumor

11 growth are ameliorated by the addition of antibody to CXCL1 [51]. These findings

combined together suggest that, under different inflammatory conditions, PGs can induce various chemokines, which then promote inflammation further (Figures 2 and 3).

In addition to induction of chemokine expression, one type of $\mathrm{PG}, \mathrm{PGD}_{2}$ can directly recruit and activate Th2 lymphocytes and eosinophils by acting on CRTH2/DP2, which belongs to the chemokine receptor family [52], and this action is exerted in various allergic conditions [53]. Such CRTH2/DP2 actions on these inflammatory cells together with actions of DP1 possibly on sensitized airway epithelium [54] 
1 contribute to elicitation of allergic inflammation in animal model of asthma.

2

$3 \quad$ PGs and tissue remodeling

4 If inflammation does not subside, it often leads to tissue remodeling. Tissue

5 remodeling includes tissue metaplasia, granulation, angiogenesis and fibrosis, and roles

6 of PGs in these processes have been reported (Figure 4). PGs, depending on their type,

7 involved tissues and contexts, either facilitate or suppress tissue remodeling. For

8 example, in the ovalbumin (OVA)-induced allergic asthma model, various genes

9 associated with tissue remodeling (including the ADAM family of tissue proteases and

10 goblet cell metaplasia) are induced in the airway epithelium, and such induction is

11 negatively modulated by $\mathrm{PGE}_{2}$-EP3 signaling [55]. Regulation of angiogenesis by PGs

12 is found in chronic inflammation models such as CIA [7] and tumor-associated

13 inflammation [40, 50, 51, 56-59] (Figure 4). Such signaling is mainly exerted by

14 mesenchymal cells involved in inflammation; synovial cells in CIA and stromal

15 fibroblasts in tumor-associated inflammation. Regulation of angiogenesis by PGs

16 involves induction of both direct angiogenic factors such as VEGF and chemokines that

17 recruit endothelial precursors to affected sites and induce tubular formation. For 
1 [7], and $\mathrm{PGE}_{2}$ induces VEGF production from cultured cancer cell lines in vitro [56, 57].

2 In addition, upregulated expression of VEGF in cancer lesions and stromal tissues via

3 EP2 or EP3 is suppressed through the inhibition of PG signaling in vivo [40, 58, 59].

4 PGs also regulate chemokine-mediated angiogenic pathways, such as CXCL12-CXCR4

5 and CXCL1-CXCR2 signaling, which promote angiogenesis via recruiting endothelial

6 precursors, and support tumourigenesis [50, 51].

$7 \quad$ Tissue fibrosis is characterized by fibroblast proliferation and excessive deposition

8 of collagen and other extracellular matrix proteins, which exceeds normal repair

9 processes for damaged tissues. Tissue fibrosis often represents the end stage of

10 inflammation by disrupting tissue architecture and functions. PGs have been reported to

11 exert both pro-fibrotic and anti-fibrotic actions (Figure 4). For example, Oga et al. [60]

12 studied bleomycin-induced pulmonary fibrosis, a model of idiopathic pulmonary

13 fibrosis of humans, and found that loss of FP attenuated pulmonary fibrosis without

14 affecting inflammatory responses and with decreased collagen synthesis in vivo,

15 indicating that $\mathrm{PGF}_{2 \alpha}-\mathrm{FP}$ signaling is involved in the fibrosis process itself. Consistent

16 with this, the addition of $\mathrm{PGF}_{2 \alpha}$ enhanced collagen synthesis in lung fibroblasts in vitro

17 in a FP-dependent manner, and, intriguingly, in a manner additive to TGF- $\beta$ [60]. These results suggest that $\mathrm{PGF}_{2 \alpha}$ functions as a pro-fibrotic mediator in pulmonary fibrosis. 
1 Indeed, levels of $\mathrm{PGF}_{2 \alpha}$ were significantly elevated in bronchial alveolar lavage fluid of

2 idiopathic pulmonary fibrosis patients [60]. By contrast, Lovgren et al. [61] found that

3 loss of COX-2 (but not loss of mPGES-1) augmented fibrosis and worsened lung

4 function in a bleomycin-induced pulmonary fibrosis model, which was mimicked by

5 loss of IP but not that of either EP2 or EP4. On the basis of these findings, they

6 suggested that $\mathrm{PGI}_{2}$-IP signaling protects against pulmonary fibrosis. A protective action

7 of $\mathrm{PGI}_{2}$-IP signaling against fibrosis was also reported in heart, where IP and TP

8 signaling appear to function antagonistically [62, 63]. These findings indicate

9 importance of selective manipulation of signaling pathways of PGs to control tissue

10 remodeling (Figure 4).

\section{Concluding remarks and future directions}

In this review, we have discussed the roles of PGs in various animal models of

14 chronic inflammation. Because the primary focus of this review is the role of PGs in transition to and maintenance of chronic inflammation, we have chosen recent finding pertinent to this role and discussed their implication. From the findings discussed here,

17 it is now clear that PGs function as more than acute inflammatory mediators, and are

18 involved in various aspects of chronic inflammation. However, in addition to the 
1 pro-inflammatory actions described here, PGs also exert anti-inflammatory and

2 immunoregulatory roles such as suppression of macrophage activation [64],

3 tumor-induced immunosuppression [65, 66] and induction of regulatory T cells [67]. It

4 is therefore important to clarify not only how PGs mediate chronic inflammation but

5 also how PG-mediated anti-inflammatory circuit is integrated and, in some cases, down

6 regulated in chronic inflammation. It is also important to examine whether PG signaling

7 induce any epigenetic changes in the process of chronic inflammation, which may be

8 very important to sustain the inflammatory state. These are future directions of

9 inflammation research. We should also point out that, due to the space limit, we do not

10 address interaction of PGs and other lipid mediators such as resolvins, which are

11 proposed to function in termination of inflammation. This topic is discussed in a recent excellent review [68]. Finally, because animal models do not exactly recapitulate all aspects of human diseases, the findings discussed here must be validated in human diseases. Nonetheless, research in this area is therapeutically important, given the burden of chronic diseases in our society, and is promising, given that selective manipulation of receptors rather than general COX and mPGES inhibition apparently provides significant benefits. 


\section{References}

1. Ben-Neriah, Y and Karin, M (2011) Inflammation meets cancer, with

NF-kappaB as the matchmaker. Nat Immunol 12, 715-723

2. Donath, MY and Shoelson, SE (2011) Type 2 diabetes as an inflammatory disease. Nat Rev Immunol 11, 98-107

3. Rader, DJ and Daugherty, A (2008) Translating molecular discoveries into new therapies for atherosclerosis. Nature 451, 904-913

4. Hirata, T and Narumiya, S (2011) Prostanoid receptors. Chem Rev 111, $6209-6230$

5. Narumiya, S (2009) Prostanoids and inflammation: a new concept arising from receptor knockout mice. J Mol Med (Berl) 87, 1015-1022

6. Narumiya, S and Furuyashiki, T (2011) Fever, inflammation, pain and beyond: prostanoid receptor research during these 25 years. FASEB J 25, 813-818 7. Honda, T, Segi-Nishida, E, Miyachi, Y and Narumiya, S (2006) Prostacyclin-IP signaling and prostaglandin $\mathrm{E}_{2}$-EP2/EP4 signaling both mediate joint inflammation in mouse collagen-induced arthritis. J Exp Med 203, 325-335 8. Chen, M, Boilard, E, Nigrovic, PA, Clark, P, Xu, D, Fitzgerald, GA, Audoly, LP and Lee DM (2008) Predominance of cyclooxygenase 1 over cyclooxygenase 2 in the generation of proinflammatory prostaglandins in autoantibody-driven $\mathrm{K} / \mathrm{BxN}$ serum-transfer arthritis. Arthritis Rheum 58, 1354-1365 9. Oshima, H, Hioki, K, Popivanova, BK, Oguma, K, Van Rooijen, N, Ishikawa, TO and Oshima, M (2011) Prostaglandin E signaling and bacterial infection recruit tumor-promoting macrophages to mouse gastric tumors. Gastroenterology 140, 596-607 10. Yao, C, Sakata, D, Esaki, Y, Li, Y, Matsuoka, T, Kuroiwa, K, Sugimoto, Y and Narumiya, S (2009) Prostaglandin $E_{2}$-EP4 signaling promotes immune inflammation through Th1 cell differentiation and Th17 cell expansion. Nat Med 15, 633-640 11. Miossec, P, Korn, T and Kuchroo, VK (2009) Interleukin-17 and type 17 helper T cells. N Engl J Med 361, 888-898

12. Fujino, S, Andoh, A, Bamba, S, Ogawa, A, Hata, K, Araki, Y, Bamba, T and Fujiyama, Y (2003) Increased expression of interleukin 17 in inflammatory bowel disease. Gut 52, 65-70

13. Lock, C, Hermans, G, Pedotti, R, Brendolan, A, Schadt, E, Garren, H, Langer-Gould, A, Strober, S, Cannella, B, Allard, J, Klonowski, P, Austin, A, Lad, N, Kaminski, N, Galli, SJ, Oksenberg, JR, Raine, CS, Heller, R and Steinman, L (2002) Gene-microarray analysis of multiple sclerosis lesions yields new targets validated in 
autoimmune encephalomyelitis. Nat Med 8, 500-508

14. Moldovan, IR, Rudick, RA, Cotleur, AC, Born, SE, Lee, JC, Karafa, MT and

Pelfrey, CM (2003) Interferon gamma responses to myelin peptides in multiple sclerosis correlate with a new clinical measure of disease progression. J Neuroimmunol 141, $132-140$

15. Tzartos, JS, Friese, MA, Craner, MJ, Palace, J, Newcombe, J, Esiri, MM and Fugger, L (2008) Interleukin-17 production in central nervous system-infiltrating T cells and glial cells is associated with active disease in multiple sclerosis. Am J Pathol 172, $146-155$

16. Bouma, G and Strober, W (2003) The immunological and genetic basis of inflammatory bowel disease. Nat Rev Immunol 3, 521-533

17. Korn, T, Bettelli, E, Oukka, M and Kuchroo, VK (2009) IL-17 and Th17 Cells. Annu Rev Immunol 27, 485-517

18. Steinman, L (2008) A rush to judgment on Th17. J Exp Med 205, 1517-1522

19. Harris, SG, Padilla, J, Koumas, L, Ray, D and Phipps, RP (2002)

Prostaglandins as modulators of immunity. Trends Immunol 23, 144-150

20. Betz, M and Fox, BS (1991) Prostaglandin $\mathrm{E}_{2}$ inhibits production of Th1 lymphokines but not of Th2 lymphokines. J Immunol 146, 108-113

\section{Chen, Q, Muramoto, K, Masaaki, N, Ding, Y, Yang, H, Mackey, M, Li, W,} Inoue, Y, Ackermann, K, Shirota, H, Matsumoto, I, Spyvee, M, Schiller, S, Sumida, T, Gusovsky, F and Lamphier, M (2010) A novel antagonist of the prostaglandin $E_{2}$ EP4 receptor inhibits Th1 differentiation and Th17 expansion and is orally active in arthritis models. Br J Pharmacol 160, 292-310

22. Boniface, K, Bak-Jensen, KS, Li, Y, Blumenschein, WM, McGeachy, MJ, McClanahan, TK, McKenzie, BS, Kastelein, RA, Cua, DJ and de Waal Malefyt, R (2009) Prostaglandin $E_{2}$ regulates Th17 cell differentiation and function through cyclic AMP and EP2/EP4 receptor signaling. J Exp Med 206, 535-548 23. Napolitani, G, Acosta-Rodriguez, EV, Lanzavecchia, A and Sallusto, F (2009) Prostaglandin $\mathrm{E}_{2}$ enhances Th17 responses via modulation of IL-17 and IFN-gamma production by memory $\mathrm{CD}^{+}{ }^{\mathrm{T}}$ cells. Eur J Immunol 39, 1301-1312

24. Chizzolini, C, Chicheportiche, R, Alvarez, M, de Rham, C, Roux-Lombard, P, Ferrari-Lacraz, S and Dayer, JM (2008) Prostaglandin $E_{2}$ synergistically with interleukin-23 favors human Th17 expansion. Blood 112, 3696-703 25. Sheibanie, AF, Tadmori, I, Jing, H, Vassiliou, E and Ganea, D (2004) Prostaglandin $\mathrm{E}_{2}$ induces IL-23 production in bone marrow-derived dendritic cells. FASEB J 18, 1318-1320 
26. Khayrullina, T, Yen, JH, Jing, H and Ganea, D (2008) In vitro differentiation of dendritic cells in the presence of prostaglandin $\mathrm{E}_{2}$ alters the IL-12/IL-23 balance and promotes differentiation of Th17 cells. J Immunol 181, 721-735

27. Nakajima, S, Honda, T, Sakata, D, Egawa, G, Tanizaki, H, Otsuka, A, Moniaga, CS, Watanabe, T, Miyachi, Y, Narumiya, S and Kabashima, K (2010) Prostaglandin $\mathrm{I}_{2}$-IP signaling promotes Th1 differentiation in a mouse model of contact hypersensitivity. J Immunol 184, 5595-5603

28. Takahashi, Y, Tokuoka, S, Masuda, T, Hirano, Y, Nagao, M, Tanaka, H, Inagaki, N, Narumiya, S and Nagai, H (2002) Augmentation of allergic inflammation in prostanoid IP receptor deficient mice. Br J Pharmacol 137, 315-22

29. Sheibanie, AF, Yen, JH, Khayrullina, T, Emig, F, Zhang, M, Tuma, R and Ganea, D (2007) The proinflammatory effect of prostaglandin $E_{2}$ in experimental inflammatory bowel disease is mediated through the IL-23-->IL-17 axis. J Immunol 178, 8138-8147

30. Sheibanie, AF, Khayrullina, T, Safadi, FF and Ganea, D (2007) Prostaglandin $\mathrm{E}_{2}$ exacerbates collagen-induced arthritis in mice through the inflammatory interleukin-23/interleukin-17 axis. Arthritis Rheum 56, 2608-2619 31. Libioulle, C, Louis, E, Hansoul, S, Sandor, C, Farnir, F, Franchimont, D, Vermeire, S, Dewit, O, de Vos, M, Dixon, A, Demarche, B, Gut, I, Heath, S, Foglio, M, Liang, L, Laukens, D, Mni, M, Zelenika, D, Van Gossum, A, Rutgeerts, P, Belaiche, J, Lathrop, M and Georges, M (2007) Novel Crohn disease locus identified by genome-wide association maps to a gene desert on 5p13.1 and modulates expression of PTGER4. PLoS Genet 3, e58

32. Sawcer, S, Hellenthal, G, Pirinen, M, Spencer, CC, Patsopoulos, NA, Moutsianas, L, Dilthey, A, Su, Z, Freeman, C, Hunt, SE, Edkins, S, Gray, E, Booth, DR, Potter, SC, Goris, A, Band, G, Oturai, AB, Strange, A, Saarela, J, Bellenguez, C, Fontaine, B, Gillman, M, Hemmer, B, Gwilliam, R, Zipp, F, Jayakumar, A, Martin, R, Leslie, S, Hawkins, S, Giannoulatou, E, D'Alfonso, S, Blackburn, H, Boneschi, FM, Liddle, J, Harbo, HF, Perez, ML, Spurkland, A, Waller, MJ, Mycko, MP, Ricketts, M, Comabella, M, Hammond, N, Kockum, I, McCann, OT, Ban, M, Whittaker, P, Kemppinen, A, Weston, P, Hawkins, C, Widaa, S, Zajicek, J, Dronov, S, Robertson, N, Bumpstead, SJ, Barcellos, LF, Ravindrarajah, R, Abraham, R, Alfredsson, L, Ardlie, K, Aubin, C, Baker, A, Baker, K, Baranzini, SE, Bergamaschi, L, Bergamaschi, R, Bernstein, A, Berthele, A, Boggild, M, Bradfield, JP, Brassat, D, Broadley, SA, Buck, D, Butzkueven, H, Capra, R, Carroll, WM, Cavalla, P, Celius, EG, Cepok, S, Chiavacci, R, Clerget-Darpoux, F, Clysters, K, Comi, G, Cossburn, M, Cournu-Rebeix, I, Cox, MB, 
1 Cozen, W, Cree, BA, Cross, AH, Cusi, D, Daly, MJ, Davis, E, de Bakker, PI,

2 Debouverie, M, D'Hooghe, M B, Dixon, K, Dobosi, R, Dubois, B, Ellinghaus, D,

3 Elovaara, I, Esposito, F, Fontenille, C, Foote, S, Franke, A, Galimberti, D, Ghezzi, A,

4 Glessner, J, Gomez, R, Gout, O, Graham, C, Grant, SF, Guerini, FR, Hakonarson, H,

5 Hall, P, Hamsten, A, Hartung, HP, Heard, RN, Heath, S, Hobart, J, Hoshi, M,

6 Infante-Duarte, C, Ingram, G, Ingram, W, Islam, T, Jagodic, M, Kabesch, M, Kermode,

7 AG, Kilpatrick, TJ, Kim, C, Klopp, N, Koivisto, K, Larsson, M, Lathrop, M,

8 Lechner-Scott, JS, Leone, MA, Leppa, V, Liljedahl, U, Bomfim, IL, Lincoln, RR, Link,

9 J, Liu, J, Lorentzen, AR, Lupoli, S, Macciardi, F, Mack, T, Marriott, M, Martinelli, V,

Mason, D, McCauley, JL, Mentch, F, Mero, IL, Mihalova, T, Montalban, X, Mottershead J, Myhr, KM, Naldi, P, Ollier, W, Page, A, Palotie, A, Pelletier, J, Piccio, L, Pickersgill, T, Piehl, F, Pobywajlo, S, Quach, HL, Ramsay, PP, Reunane,n M, Reynolds, R, Rioux, JD, Rodegher, M, Roesner, S, Rubio, JP, Ruckert, IM, Salvetti, M, Salvi, E, Santaniello, A, Schaefer, CA, Schreiber, S, Schulze, C, Scott, RJ, Sellebjerg, F, Selmaj, KW, Sexton, D, Shen, L, Simms-Acuna, B, Skidmore, S, Sleiman, PM, Smestad, C, Sorensen, PS, Sondergaard, HB, Stankovich, J, Strange, RC, Sulonen, AM, Sundqvist, E, Syvanen, AC, Taddeo, F, Taylor, B, Blackwell, JM, Tienari, P, Bramon, E, Tourbah, A, Brown, MA, Tronczynska, E, Casas, JP, Tubridy, N, Corvin, A, Vickery, J, Jankowski, J, Villoslada, P, Markus, HS, Wang, K, Mathew, CG, Wason, J, Palmer, CN, Wichmann, HE, Plomin, R, Willoughby, E, Rautanen, A, Winkelmann, J, Wittig, M, Trembath, RC, Yaouanq, J, Viswanathan, AC, Zhang, H, Wood, NW, Zuvich, R, Deloukas P, Langford, C, Duncanson, A, Oksenberg, JR, Pericak-Vance, MA, Haines JL, Olsson, T, Hillert, J, Ivinson, AJ, De Jager, PL, Peltonen, L, Stewart, GJ, Hafler, DA, Hauser, SL, McVean, G, Donnelly, P and Compston, A (2011) Genetic risk and a primary role for cell-mediated immune mechanisms in multiple sclerosis. Nature 476, 214-219 33. Wiebers, DO, Piepgras, DG, Brown, RD, Jr., Meissner, I, Torner, J, Kassell, NF, Whisnant, JP, Huston, J, 3rd and Nichols, DA (2002) Unruptured aneurysms. J Neurosurg 96, 50-51 34. van Gijn, J, Kerr, RS and Rinkel, GJ (2007) Subarachnoid haemorrhage. Lancet 369, 306-318 35. Aoki, T, Nishimura, M, Matsuoka, T, Yamamoto, K, Furuyashiki, T, Kataoka, H, Kitaoka, S, Ishibashi, R, Ishibazawa, A, Miyamoto, S, Morishita, R, Ando, J, Hashimoto, N, Nozaki, K and Narumiya, S (2011) PGE $_{2}$-EP2 signalling in endothelium is activated by haemodynamic stress and induces cerebral aneurysm through an amplifying loop via NF- $\kappa$ B. Br J Pharmacol 163, 1237-1249 
1 Tiano, HF, Morham, SG, Smithies, O and Langenbach, R (2000) Genetic disruption of

2 Ptgs-1, as well as Ptgs-2, reduces intestinal tumorigenesis in Min mice. Cancer Res 60,

$3 \quad 4705-4708$

4 37. Oshima, M, Dinchuk, JE, Kargman, SL, Oshima, H, Hancock, B, Kwong, E,

5 Trzaskos, JM, Evans, JF and Taketo, MM (1996) Suppression of intestinal polyposis in

$6 \mathrm{Apc}^{\Delta 716}$ knockout mice by inhibition of cyclooxygenase 2 (COX-2). Cell 87, 803-809

$7 \quad 38$. Janne, PA and Mayer, RJ (2000) Chemoprevention of colorectal cancer. N Engl

8 J Med 342, 1960-1968

9 39. Rothwell, PM, Wilson, M, Elwin, CE, Norrving, B, Algra, A, Warlow, CP and

10 Meade, TW (2010) Long-term effect of aspirin on colorectal cancer incidence and

11 mortality: 20-year follow-up of five randomised trials. Lancet 376, 1741-1750

12 40. Sonoshita, M, Takaku, K, Sasaki, N, Sugimoto, Y, Ushikubi, F, Narumiya, S,

13 Oshima, M and Taketo, MM (2001) Acceleration of intestinal polyposis through

14 prostaglandin receptor EP2 in Apc ${ }^{\Delta 716}$ knockout mice. Nat Med 7, 1048-1051

15 41. Shin, VY, Jin, H, Ng, EK, Cheng, AS, Chong, WW, Wong, CY, Leung, WK,

16 Sung, JJ and Chu, KM (2011) NF- $\kappa$ B targets miR-16 and miR-21 in gastric cancer:

17 involvement of prostaglandin E receptors. Carcinogenesis 32, 240-245

18 42. Catassi, A, Servent, D, Paleari, L, Cesario, A and Russo, P (2008) Multiple

19 roles of nicotine on cell proliferation and inhibition of apoptosis: implications on lung

20 carcinogenesis. Mutat Res 659, 221-231

21 43. Erez, N, Truitt, M, Olson, P, Arron, ST and Hanahan, D (2010)

22 Cancer-Associated Fibroblasts Are Activated in Incipient Neoplasia to Orchestrate

23 Tumor-Promoting Inflammation in an NF-кB-Dependent Manner. Cancer Cell 17, $24 \quad 135-147$

44. Benoit, V, de Moraes, E, Dar, NA, Taranchon, E, Bours, V, Hautefeuille, A, Taniere, P, Chariot, A, Scoazec, JY, de Moura Gallo, CV, Merville, MP and Hainaut, P (2006) Transcriptional activation of cyclooxygenase-2 by tumor suppressor p53 requires nuclear factor-kappa B. Oncogene 25, 5708-5718 45. St-Germain, ME, Gagnon, V, Parent, S and Asselin, E (2004) Regulation of COX-2 protein expression by Akt in endometrial cancer cells is mediated through $\mathrm{NF}-\kappa \mathrm{B} / \mathrm{I} \kappa \mathrm{B}$ pathway. Mol Cancer 3, 7 46. Neufert, C, Becker, C and Neurath, MF (2007) An inducible mouse model of colon carcinogenesis for the analysis of sporadic and inflammation-driven tumor progression. Nat Protoc 2, 1998-2004 
formation. Stroke 40, 942-951

48. Aoki, T, Kataoka, H, Morimoto, M, Nozaki, K and Hashimoto, N (2007)

Macrophage-derived matrix metalloproteinase-2 and -9 promote the progression of cerebral aneurysms in rats. Stroke 38, 162-169

49. Kanematsu, Y, Kanematsu, M, Kurihara C, Tada, Y, Tsou, TL, van Rooijen, N, Lawton, MT, Young, WL, Liang, EI, Nuki, Y and Hashimoto, T (2011) Critical roles of macrophages in the formation of intracranial aneurysm. Stroke 42, 173-178 50. Katoh, H, Hosono, K, Ito, Y, Suzuki, T, Ogawa, Y, Kubo, H, Kamata, H, Mishima, T, Tamaki, H, Sakagami, H, Sugimoto, Y, Narumiya, S, Watanabe, M and Majima, M (2010) COX-2 and prostaglandin EP3/EP4 signaling regulate the tumor stromal proangiogenic microenvironment via CXCL12-CXCR4 chemokine systems. Am J Pathol 176, 1469-1483

51. Wang, D, Wang, H, Brown, J, Daikoku, T, Ning, W, Shi, Q, Richmond, A, Strieter, R, Dey, SK and DuBois, RN (2006) CXCL1 induced by prostaglandin $\mathrm{E}_{2}$ promotes angiogenesis in colorectal cancer. J Exp Med 203, 941-951

52. Hirai, H, Tanaka, K, Yoshie, O, Ogawa, K, Kenmotsu, K, Takamori, Y, Ichimasa, M, Sugamura, K, Nakamura, M, Takano, S and Nagata, K (2001) Prostaglandin $\mathrm{D}_{2}$ selectively induces chemotaxis in T helper type 2 cells, eosinophils, and basophils via seven-transmembrane receptor CRTH2. J Exp Med 193, 255-261 53. Shiraishi, Y, Asano, K, Niimi, K, Fukunaga, K, Wakaki, M, Kagyo, J, Takihara, T, Ueda S, Nakajima T, Oguma, T, Suzuki, Y, Shiomi, T, Sayama, K, Kagawa, S, Ikeda, E, Hirai, H, Nagata, K, Nakamura, M, Miyasho, T and Ishizaka, A (2008) Cyclooxygenase-2/prostaglandin $\mathrm{D}_{2} / \mathrm{CRTH} 2$ pathway mediates double-stranded RNA-induced enhancement of allergic airway inflammation. J Immunol 180, 541-549 54. Matsuoka, T, Hirata, M, Tanaka, H, Takahashi, Y, Murata, T, Kabashima, K, Sugimoto, Y, Kobayashi, T, Ushikubi, F, Aze, Y, Eguchi, N, Urade, Y, Yoshida, N, Kimura, K, Mizoguchi, A, Honda Y, Nagai, H and Narumiya, S (2000) Prostaglandin $\mathrm{D}_{2}$ as a mediator of allergic asthma. Science 287, 2013-2007

55. Kunikata, T, Yamane, H, Segi, E, Matsuoka, T, Sugimoto, Y, Tanaka, S, Tanaka, H, Nagai, H, Ichikawa, A and Narumiya, S (2005) Suppression of allergic inflammation by the prostaglandin E receptor subtype EP3. Nat Immunol 6, 524-531

56. Park, SW, Kim, HS, Choi, MS, Jeong, WJ, Heo, DS, Kim, KH and Sung, MW (2011) The effects of the stromal cell-derived cyclooxygenase-2 metabolite prostaglandin $\mathrm{E}_{2}$ on the proliferation of colon cancer cells. J Pharmacol Exp Ther 336, 516-523

57. Spinella, F, Rosano, L, Di Castro, V, Natali, PG and Bagnato, A (2004) 
1 Endothelin-1-induced prostaglandin $\mathrm{E}_{2}$-EP2, EP4 signaling regulates vascular

2 endothelial growth factor production and ovarian carcinoma cell invasion. J Biol Chem

$3279,46700-46705$

4 58. Amano, H, Hayashi, I, Endo, H, Kitasato, H, Yamashina, S, Maruyama, T,

5 Kobayashi, M, Satoh, K, Narita, M, Sugimoto, Y, Murata, T, Yoshimura, H, Narumiya,

$6 \quad$ S and Majima, M (2003) Host prostaglandin $E_{2}$-EP3 signaling regulates

7 tumor-associated angiogenesis and tumor growth. J Exp Med 197, 221-232

8 59. Kamata, H, Hosono, K, Suzuki, T, Ogawa, Y, Kubo, H, Katoh, H, Ito, Y,

9 Uematsu, S, Akira, S, Watanabe, M and Majima, M (2010) mPGES-1-expressing bone

\section{Pharmacother 64, 409-416}

60. Oga, T, Matsuoka, T, Yao, C, Nonomura, K, Kitaoka, S, Sakata, D, Kita, Y, Tanizawa, K, Taguchi, Y, Chin, K, Mishima, M, Shimizu, T and Narumiya, S (2009) Prostaglandin $\mathrm{F}_{2 \alpha}$ receptor signaling facilitates bleomycin-induced pulmonary fibrosis independently of transforming growth factor- $\beta$. Nat Med 15, 1426-1430 61. Lovgren, AK, Jania, LA, Hartney, JM, Parsons, KK, Audoly, LP, Fitzgerald, GA, Tilley, SL and Koller, BH (2006) COX-2-derived prostacyclin protects against bleomycin-induced pulmonary fibrosis. Am J Physiol Lung Cell Mol Physiol 291,

\section{L144-156}

62. Francois, H, Athirakul, K, Howell, D, Dash, R, Mao, L, Kim, HS, Rockman, HA, Fitzgerald, GA, Koller, BH and Coffman, TM (2005) Prostacyclin protects against elevated blood pressure and cardiac fibrosis. Cell Metab 2, 201-207 63. Wang, D, Patel, VV, Ricciotti, E, Zhou, R, Levin, MD, Gao, E, Yu, Z, Ferrari, VA, Lu, MM, Xu, J, Zhang, H, Hui, Y, Cheng, Y, Petrenko, N, Yu, Y and FitzGerald, GA (2009) Cardiomyocyte cyclooxygenase-2 influences cardiac rhythm and function. Proc Natl Acad Sci U S A 106, 7548-7552

64. Eruslanov, E, Daurkin, I, Ortiz, J, Vieweg, J and Kusmartsev, S (2010) Pivotal Advance: Tumor-mediated induction of myeloid-derived suppressor cells and 9 M2-polarized macrophages by altering intracellular PGE catabolism in myeloid cells. J Leukoc Biol 88, 839-848

1 65. Sinha, P, Clements, VK, Fulton, AM and Ostrand-Rosenberg, S (2007)

2 Prostaglandin $\mathrm{E}_{2}$ promotes tumor progression by inducing myeloid-derived suppressor 3 cells. Cancer Res 67, 4507-4513

34 66. Sharma, S, Yang, SC, Zhu, L, Reckamp, K, Gardner, B, Baratelli, F, Huang, M, 5 Batra, RK and Dubinett, SM (2005) Tumor cyclooxygenase-2/prostaglandin $36 \mathrm{E}_{2}$-dependent promotion of FOXP3 expression and $\mathrm{CD} 4^{+} \mathrm{CD} 25^{+} \mathrm{T}$ regulatory cell 
1 activities in lung cancer. Cancer Res 65, 5211-5220

2 67. Soontrapa, K, Honda, T, Sakata, D, Yao, C, Hirata, T, Hori, S, Matsuoka, T,

3 Kita, Y, Shimizu, T, Kabashima, K and Narumiya, S (2011) Prostaglandin

$4 \quad \mathrm{E}_{2}$-prostaglandin E receptor subtype 4 (EP4) signaling mediates UV irradiation-induced

5 systemic immunosuppression. Proc Natl Acad Sci U S A 108, 6668-6673

6 68. Levy BD (2010) Resolvins and protectins: natural pharmacophores for

7 resolution biology. Prostaglandins Leukot Essent Fatty Acids 82, 327-332

8

9

\section{Figure Legends}

Figure 1. The role of prostaglandin system as a cytokine amplifier.

The contribution of prostaglandin system to the amplification of cytokine signaling is shown. Cytokines in blue are those whose signaling is amplified by the prostaglandin system. PGE 2 synergistically induces IL-6/IL-1 $\beta / C O X-2$ expression with LPS via EP4 in macrophages (red dashed box at upper left) [9]. $\mathrm{PGE}_{2}$ also promotes the differentiation of Th1 from naïve T cells synergistically with IL-12 via EP2/EP4 (red dashed box at upper right) [10]. $\mathrm{PGE}_{2}$ stimulates dendritic cells (DCs) and promotes IL-23 production synergistically with CD40 and toll-like receptor (TLR) signaling. $\mathrm{PGE}_{2}$ then enhances the expansion of Th17 cells with IL-23 (red dashed box at lower right) $[10,21,25,26]$. $\mathrm{PGI}_{2}$ also induces pro-inflammatory cytokines such as IL-6 from synovial fibroblasts synergistically with IL-1 $\beta$ (red dashed box at lower left ) [7].

Figure 2. The proposal mechanisms of chronicity of inflammation contributing to 
1 intracranial aneurysm formation.

2 Positive feedback loop consisting of $\mathrm{COX}-2-\mathrm{PGE}_{2}-\mathrm{EP} 2-\mathrm{NF}-\kappa \mathrm{B}$ and macrophage

3 infiltration in arterial walls by $\mathrm{NF}-\kappa \mathrm{B}$-mediated $\mathrm{MCP}-1$ expression contribute to the

4 chronic inflammation responsible for intracranial aneurysm formation .

6 Figure 3. The contribution of prostaglandin system to the recruitment of immune cells.

$7 \quad \mathrm{PGE}_{2}$ and $\mathrm{PGI}_{2}$ induce chemoattractants (MCP-1, CXCL12, CXCL7) resulting in the

8 recruitment of inflammatory cells to affected sites.

9

10 Figure 4. The contribution of prostaglandin system to tissue remodeling.

11 Prostaglandin system promotes or suppresses tissue remodeling, including metaplasia,

12 fibrosis and angiogenesis, in a context-dependent manner. Red or blue color indicates

13 the contribution of prostaglandin system to the promotion or suppression of tissue

14 remodeling, respectively. 
Figure 1.

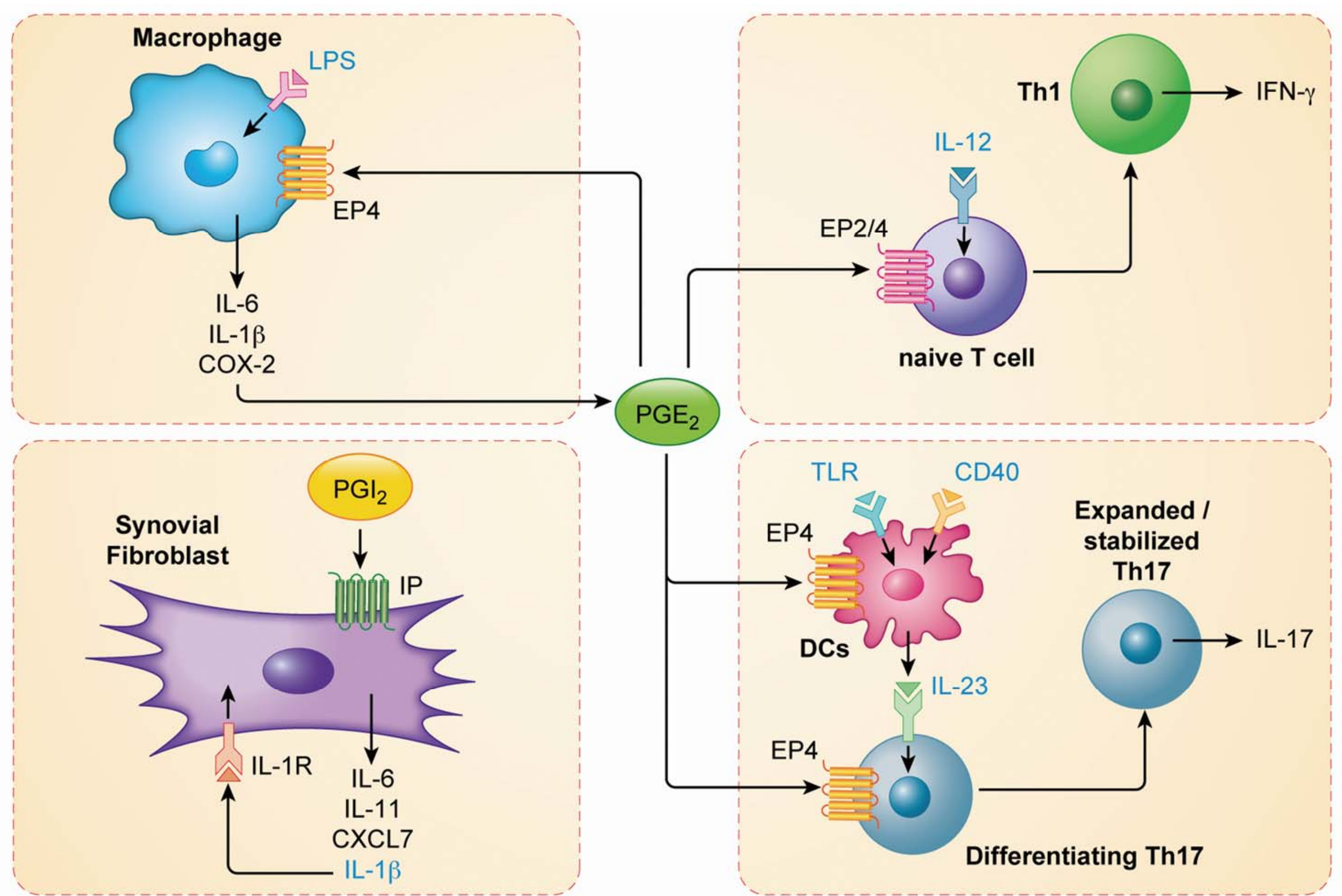




\section{Figure 2.}

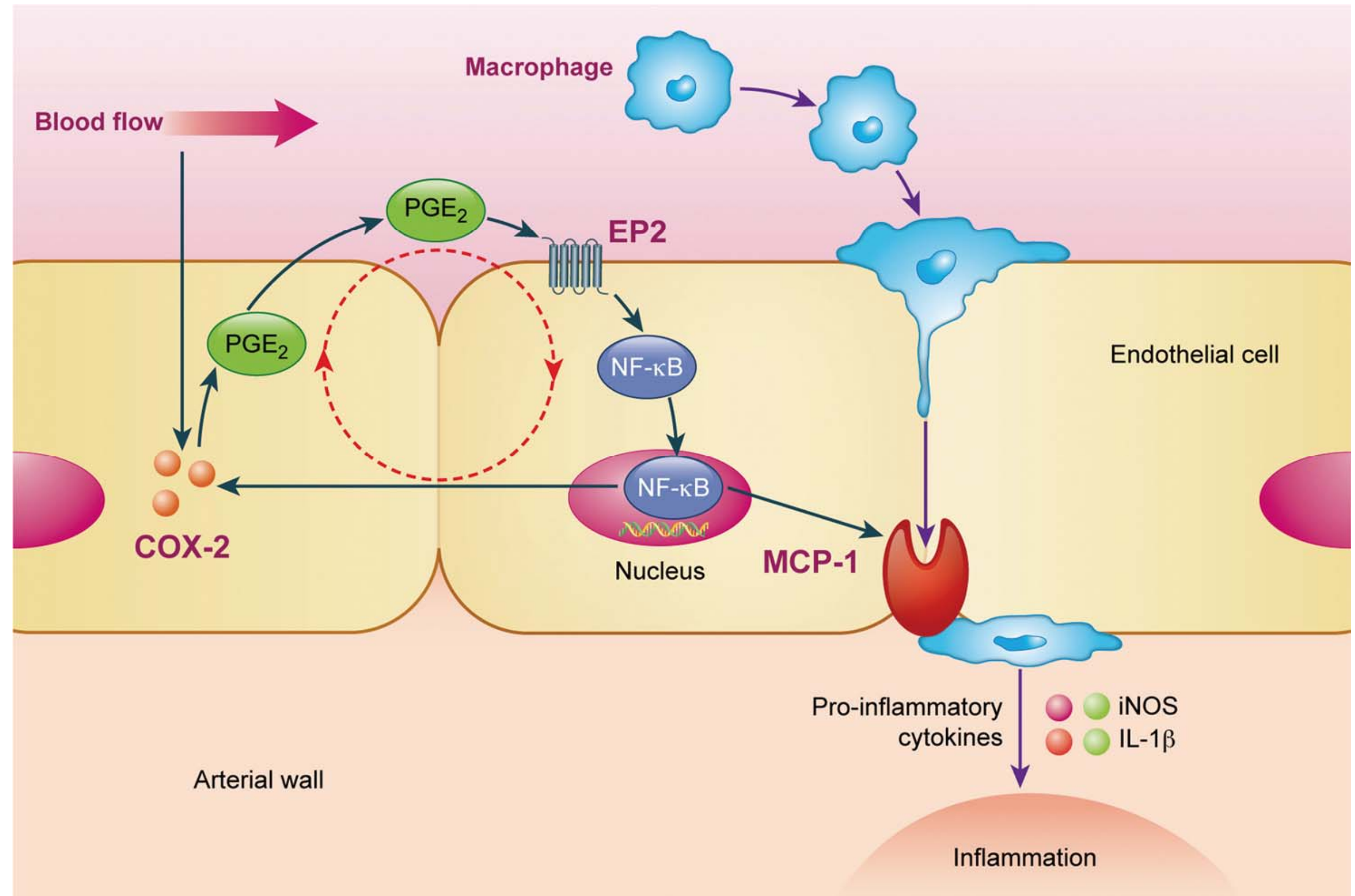




\section{Figure 3.}

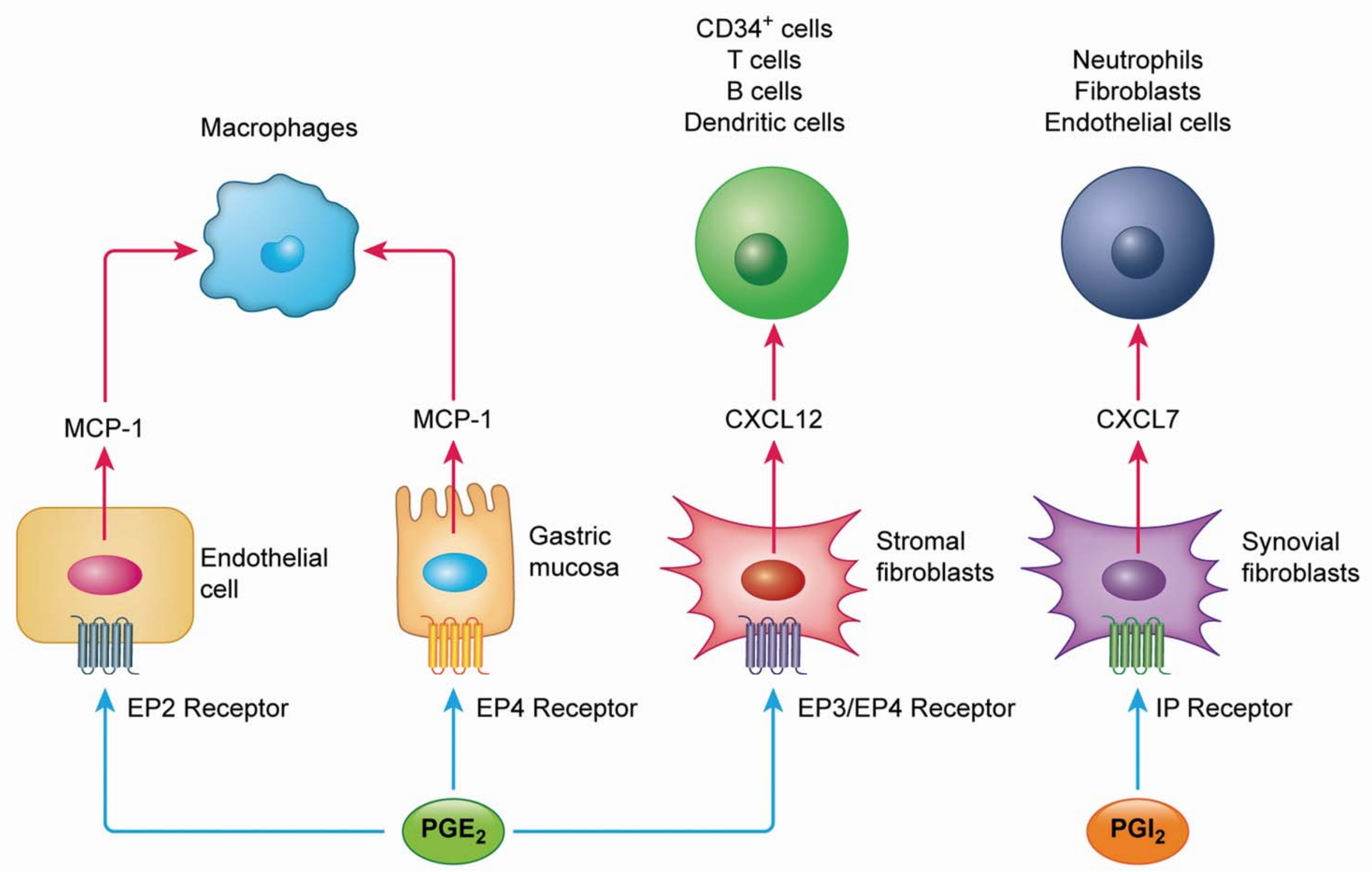




\section{Figure 4.}

\section{Tissue Remodeling}

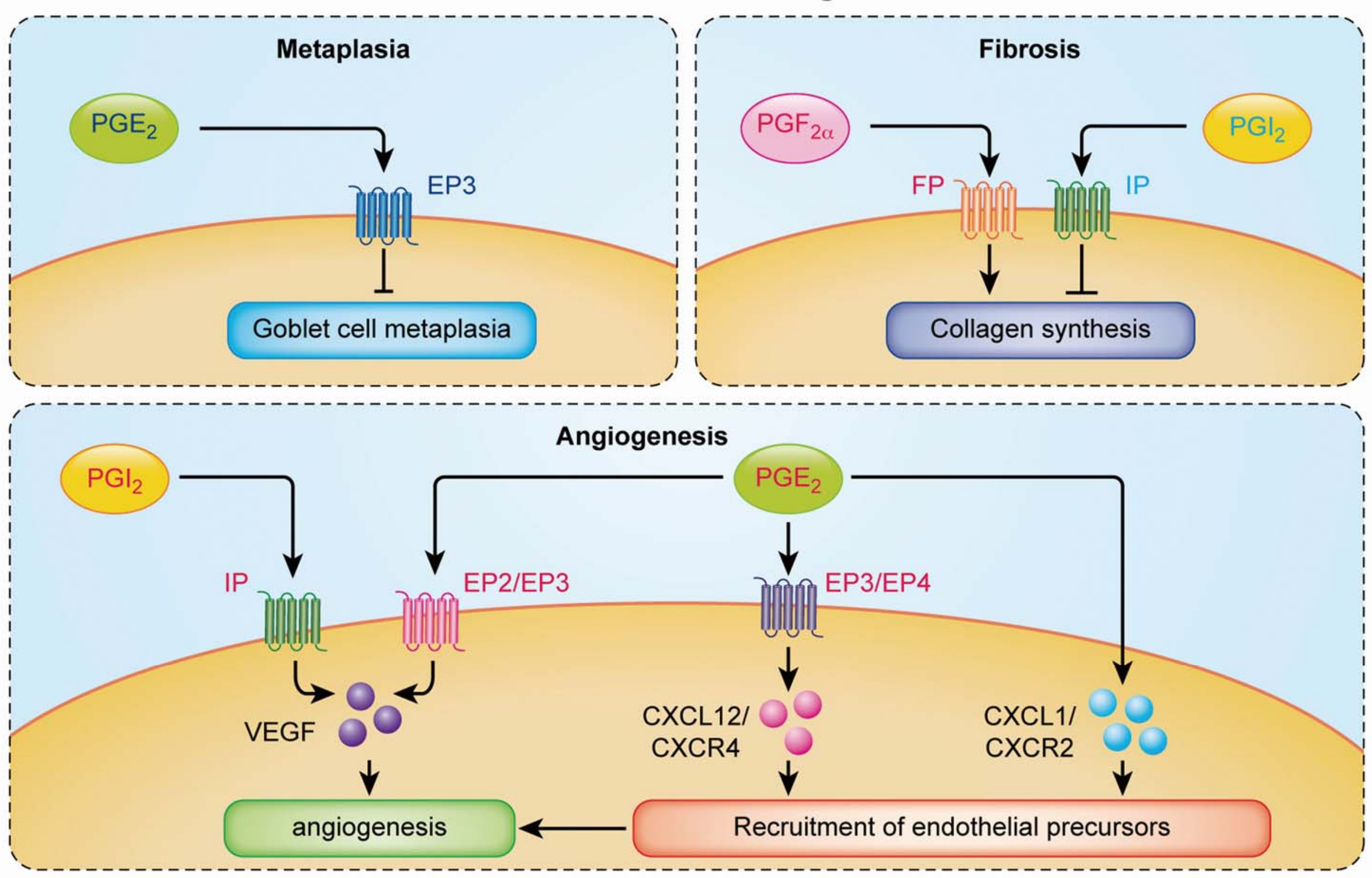

